\title{
Wstęp
}

\section{Errare humanum est - o niebezpieczeństwach błędów i pożytkach z omylności}

\section{Agnieszka Bąbel}

ORCID: 0000-0002-I82I-9399

(Instytut Badań Literackich PAN, Warszawa)

Rozprawienie się z btędem przynosi równe, a czasem nawet większe korzyści, niż odkrycie nowej prawdy lub faktu. Słowa przypisywane Karolowi Darwinowi ${ }^{\mathrm{T}}$

Historia nauki jest pełna anegdot o błędach uczonych, które stały się zarodkiem wielkich odkryć, lub o nie mniej wielkich umysłach wygłaszających fałszywe opinie, zweryfikowane przez czas. Szczególnie wdzięcznym polem, na którym bujnie plenią się takie przypadki, są tereny pograniczne między różnymi dyscyplinami naukowymi lub burzliwe okresy powstawania nowych dziedzin. Tak na przykład w cenionej do dziś surrealistycznej satyrze na oświeceniową naukę i relacje społeczne, jaką są Podróże Guliwera (wydanie poprawione z I735 roku), Jonathan Swift pokpiwał z szalonych eksperymentów z „wyciąganiem z ogórków promieni słonecznych”, które dla wtajemniczonych czytelników były wyraźną parodią pracy proboszcza z Hampshire, Stephena Halesa o „statyce roślin” z I727 roku. W następnych pokoleniach (w latach I77I-I772) kontynuator tych badań, ekscentryczny chemik Joseph Priestley, analizując tak fascynującą naukowców wieku świateł naturę powietrza, potwierdzil, że zamknięta w hermetycznym słoju gałązka mięty odtwarza wypalony przez świecę tlen, czym położył podwaliny pod poznanie procesu fotosyntezy ${ }^{2}$.

1 Cyt. za: G. Stix, Dziedzictwo Darwina, „Świat Nauki” 2009, nr 2 (210), s. 23.

2 R. Mabey, Roślinny kabaret. Botanika i wyobraźnia, tłum. M. Witkowska, Warszawa 2018, s. 232-236 . 
Wbrew znanej sentencji, wielkie umysły wcale nie zawsze myślą podobnie, a wielu odkryć lub opracowania nowych metodologii dokonano, powracając do odrzuconych niegdyś jako błędne założeń i patrząc na nie z odmiennej perspektywy lub badając dostępny materiał przy użyciu innego instrumentarium³ ${ }^{3}$ Wizja niezachwianie linearnego rozwoju, naturalnej kumulacji wiedzy i eksperymentu, który - jeśli tylko został dobrze zaplanowany - musi zakończyć się sukcesem, jest tyleż pociągająca, co złudna i bardzo niebezpieczna w swoim uproszczeniu.

Grantowy model badań naukowych, na co zwracano uwagę już od lat, nie toleruje błędu jako elementu nierozerwalnie wpisanego w metodę eksperymentalną - rozliczenie zadania wymaga bowiem dokładnego osiągnięcia pierwotnie założonych rezultatów. Podejście to jest dla nauki wprawdzie skuteczne na krótki dystans, lecz zabójcze w szerszej perspektywie, ponieważ ogromnie zawęża pole badań. By posłużyć się metaforą - zamienia uczonego z archeologa, próbującego odczytać zapisane w materialnych śladach dzieje skomplikowanej i różnorodnej przeszłości, w wynajętego detektywa, poszukującego wyłącznie śladów mordercy i pogardliwie odrzucającego wszelkie niezwiązane ze swoją konkretną sprawą znaleziska jako śmieci, „odpad badawczy”. Tymczasem pomysł planowania odkryć naukowych stanowi sprzeczność samą w sobie, co podkreśla fizyk i historyk fizyki, Andrzej Kajetan Wróblewski, stwierdzając:

》 Z tego [uproszczonego przedstawiania rozwoju nauki - A. B.] tworzy się dość zafałszowany obraz historii. Ludziom, którzy są daleko od danej dziedziny, wydaje się, że to takie proste - myśleli, wymyślili, zaplanowali, odkryli. Cała warstwa błędów, zakrętów, przypadków, ślepych uliczek się chowa ${ }^{4}$.

Przedstawiany XXVI numer rocznika „Napis. Pismo Poświęcone Literaturze Okolicznościowej i Użytkowej” głównym tematem rozważań czyni właśnie ową wstydliwą, często ukrywaną warstwę omyłek i „ślepych uliczek” w humanistyce,

3 Do takich „wielkich powracających" z dziedziny nauk przyrodniczych należy Jean-Baptiste Lamarck, który przed Darwinem sformułował teorię ewolucji organizmów żywych - „lamarckizm”, skompromitowany częściowo z przyczyn politycznych przez Trofima Łysenkę i jego pseudonaukowe działania. Jeszcze trzydzieści lat temu francuski przyrodnik był w podręcznikach szkolnych krytykowany, a jego koncepcja została uznana za błędną i pełną rażących uproszczeń (głównie z uwagi na założenie o możliwości dziedziczenia cech nabytych). Obecnie stanowi jedno z fundamentalnych założeń epigenetyki i badań nad horyzontalnym transferem genów (zob. R. Mabey o pracach Barbary McClintock nad genomem kukurydzy, co przyczyniło się do podważenia tezy o niezmienności genomu organizmu, Roślinny kabaret..., s. 183-185). Podobne powroty metodologii można zaobserwować w naukach o literaturze - np. pogardzany niegdyś biografizm czy inspiracje marksistowskie.

4 Historie elementarne, [wywiad] z Andrzejem Kajetanem Wróblewskim rozmawia Patrycja Dołowy, „Akademia. Magazyn Polskiej Akademii Nauk”2010, nr 4 (24): Przypadek, s. 40-41. 
obierając sobie jako tytul Errare humanum est. Btędy w badaniach humanistycznych, ich rodzaje i konsekwencje.

Błąd ma jednak podwójne oblicze - jest nierozłącznie związany z istotą badań naukowych, niekiedy fortunny (wtedy zyskuje przychylniejszą nazwę przypadku), znacznie częściej bywa szkodliwy, a może też okazać się zdumiewająco trwały i trudny do zwalczenia jako część ogólnie przyjętego światopoglądu. Taka omyłka w jakiejś mierze pasożytuje na prawdzie, żywi się nią, zniekształcając jej elementy, co szczególnie dobrze widać w kulturze masowej, która tak chętnie wykorzystuje porządkującą i uspokajającą moc uproszczeń czy stereotypów. Każda dziedzina ma własne zmory-slogany, które zdają się prawie niemożliwe do zwalczenia (dla ewolucjonistów będą to na przykład hasła w rodzaju „ludzie pochodzą od małpy” czy „darwinizm społeczny”; dla mediewistów okrzyki: „wracamy do średniowiecza, czasów palenia czarownic").

Mogłoby się zdawać, że w epoce powszechnej digitalizacji zbiorów dostęp do źródeł i możliwość rozpowszechniania poprawionej wersji są już tak ułatwione, że skorygowanie omyłki winno następować szybko i skutecznie. Jak pokazuje Tadeusz Budrewicz w artykule o długim trwaniu pomyłek, w erze internetu błąd rozpowszechnia się równie łatwo, co w epokach rękopisu czy druku, a w dodatku tym dobitniej objawia swoją wirusową naturę - fałszywa atrybucja autorska, mylne odczytanie tekstu, nieprawdziwe rozwiązanie pseudonimu, wszystko to jest w dobrej wierze błyskawicznie replikowane za mniej czy bardziej uznanymi bazami danych lub popularnymi portalami internetowymi i pojawia się ciągle mimo ponawianych wysiłków sprostowania. Literaturoznawcy borykają się nie tylko z utrwalonymi nieprawdziwymi informacjami czy dominującym modelem jedynej, kanonicznej interpretacji utworu, ale także z całą skomplikowaną sferą jego recepcji, zanikającej znajomości realiów i aluzji, a ponadto nieuniknioną skłonnością do rzutowania na świat przedstawiony dzieła własnych poglądów, doświadczeń i wyobrażeń. Zdarzają się sytuacje, kiedy jakaś pozatekstowa wypowiedź autora lub jego zachowania jako rzeczywistej osoby bardzo silnie wpływają na sposób odbioru i oceny utworu - do tego stopnia, że kontekst zaczyna dominować nad właściwym tekstem (wspomina o tym Izabela Poniatowska w artykule poświęconym recepcji twórczości Tadeusza Dołęgi-Mostowicza w polskich badaniach historycznoliterackich i refleksji krytycznej). Ale i pozornie nierozłączna opozycja wiedzy i wiary przy głębszych badaniach ukazuje swoje zastanawiające oblicze, czego dowodzi otwierająca tom rozprawa Edwarda M. Świderskiego Just where is the error? Or: epistemology as the history of error? Narodziny epistemologii, która w omawianej na wybranych przykładach krytycznej autorefleksji filozoficznej bywa uznawana za błędną, a przynajmniej nie do końca satysfakcjonującą drogę, łączy się tu z rozczarowaniem omylnością 
odwiecznych autorytetów i uświadomieniem sobie możliwej fałszywości modelu świata opartego na wierze - który doprowadził do siedemnastowiecznych wojen religijnych, a w ich następstwie do fundamentalnej rewolucji w myśleniu. U źródeł nauki o poznaniu leży więc zwątpienie, pytanie o możliwość dotarcia do prawdy, świadomość ograniczeń - związanych nie tylko z materią świata i instrumentami badawczymi, ale również z naturą poznającego podmiotu - nieufność wobec rzekomej stałości paradygmatów i wiedza o wiecznej konieczności korygowania własnych omyłek.

Motyw ten podejmuje kolejny autor, Konstantin Barszt, rozpoczynając swój artykuł od obrazu uczonego jako jednostki nieustannie popełniającej błędy, która musi pamiętać, że ciągły proces badawczy nierzadko zmienia oczywiste wyniki $\mathrm{w}$ pomyłki, uznane metodologie w przesądy, a zasady w mity. Rozprawa petersburskiego badacza przedstawia zwięzłą typologię błędów w badaniach naukowych (polegających na weryfikacji, analizie powtarzalności): I. oszustwo (fałsz, plagiat); 2. błąd metodologiczny (teoretyczny - sprzeczność logiczna i faktyczny - brak informacji lub szum informacyjny); 3. nieprecyzyjne formułowanie wniosków; 4. omyłki w procesie badawczym na poziomie organizacji. Błędem „zewnętrznym” jest presja ideologiczna ze strony władzy, która przeradza się w zakaz, cenzurę, wreszcie - skłonność do lekceważenia faktów, co przynosi tak fatalne dla rozwoju nauki skutki. Jako tekstolog, autor podejmuje na przykładzie rękopisów Fiodora Dostojewskiego próbę ukazania charakterystycznych dla tej dziedziny omyłek, zdarzających się zarówno na poziomie pracy z tekstem, takich jak: niepoprawne odczytania ${ }^{5}$, zawężanie pojęcia rękopisu (chociażby pomijanie rysunków zawartych w manuskrypcie), wpływ interpunkcji na znaczenie tekstu; jak i na poziomie przyjętych założeń: błąd narzucania z góry przyjętego kodu interpretacji fenomenowi artystycznemu dzieła (które wszak nie jest realizacją normy językowej), niewłaściwy wybór projektowanego adresata, a co za tym idzie - nietrafne rozpoznanie przeznaczenia tekstu, w końcu nieczytelność dawnego kontekstu kulturowo-językowego. Wszystkie te pułapki sprzyjają postulowaniu zachowania zdrowego empiryzmu przyjęcia jako podstawowej zasady tego, że to materiał winien dyktować badaczowi wybór właściwej metody.

Przed uczonymi specjalizującymi się w naukach humanistycznych staje dodatkowe wyzwanie i niebezpieczeństwo. Ujmujemy wyniki naszych badań w formę spójnej opowieści, która ma tłumaczyć pewne aspekty świata, i możemy nieopatrznie dać się porwać magii narracji. Widoczne jest to zwłaszcza w opracowaniach o charakterze

5 Każdy badacz posiadający doświadczenie edytorskie może z własnej praktyki przytoczyć wiele przykładów, kiedy błędne odczytanie wpływa na sens sceny, znacząco zmienia ocenę bohatera czy fałszuje datację utworu. Te rewelacje są bodaj najciekawszą częścią komentarza w przygotowywanym wydaniu krytycznym, a dla edytora stanowią zarówno powód do słusznej dumy, jak i groźne memento. 
biograficznym, kiedy to niemożność (lub nieumiejętność) dotarcia do materiałów źródłowych, niechęć do opatrywania swoich hipotez ciągłymi zastrzeżeniami albo co gorsza, faworyzowanie kuszących schematów narracyjnych ponad różnorodną i niełatwą do zinterpretowania faktografię (by nie mówić już o poszukiwaniu sensacji), mogą zamienić rzetelną pracę w opowieść podwójnie baśniową. Podwójnie - bo ulegając właściwej ludzkiej naturze potrzebie dopatrywania się logicznych wzorów w często przypadkowych zbiorach zdarzeń, jesteśmy skłonni interpretować je wedle z góry wybranego klucza, a także zastępować potwierdzone w źródłach informacje fantazją, która pozwala na wypełnienie luk w opowieści. W najnowszym tomie „Napisu” znajdziemy krytyczne analizy takich publikacji, które mogą stanowić wprost wzorcowe przykłady „uwiedzenia z góry obraną narracją” (artykuł Marleny Sęczek Ślady zapomnianej tożsamości. O roli źródet w biografi Janusza Korczaka). Ostrzeżenie przed bezkrytyczną wiarą w informacje pochodzące od twórcy, który w znacznym stopniu kreuje przecież własną biografię, zawiera tekst Grażyny Pawlak na temat wojennych doświadczeń Jana Parandowskiego.

Artykuły zgromadzone w dziale edytorskim, na zróżnicowanym materiale, obejmującym głównie utwory oświeceniowe, ale także publikacje edytorów dziewiętnastowiecznych (rozprawa Jacka Głażewskiego o wydawcach Jana Gawińskiego) i współczesnych (trzy inedita jako errata do tomu poetyckiego Antoniego Pawlaka, zamieszczone w artykule Wiktora Gardockiego), ukazują rozmaite aspekty edytorstwa pojmowanego przede wszystkim jako szacunek dla źródła, żmudna, staranna i czasochłonna praca nad tekstem. Proces ten rozpoczyna się już na etapie gotowości twórcy do poprawiania własnych rzeczowych omyłek czy szlifowania stylu (artykuł Magdaleny Bober-Jankowskiej Btad czy wariant? O technikach redakcyjnych Adama Naruszewicza). Jednak spotykana w dzisiejszych bazach bibliograficzno-tekstowych zasada, w myśl której tłumacz staje się współautorem tekstu, redaktor zaś i wydawca dzielą z twórcą odpowiedzialność za ostateczny kształt dzieła, zdaje się pojawiać już w czasach saskich, o czym świadczą przykłady zgromadzone i skrupulatnie przeanalizowane przez Bożenę Mazurkową w pracy Potknięcia impresorów i wypowiedzi w sprawie omytek druku w ksiqżce drugiej potowy XVIII wieku. Rekonesans. Errata (w dzisiejszym ekosystemie tekstów naukowych gatunek niemal ginący) stanowi ważną część dawnej książki, świadectwo kontrolowania swej pracy przez autora i wydawcę oraz zachętę dla czytelnika do uważnej, krytycznej lektury, która pozwoli mu dostrzec pominięte „myłki” w druku.

Zmieniające się na przestrzeni wieków reguły i modele edytorstwa łączyła postawa wartościująca wobec dzieła i jego przekazów - odróżnianie wersji „lepszych” i „gorszych”, odczytań mniej i bardziej prawdopodobnych (ukształtowana w XVII-XVIII stuleciu zasada lectio difficilior potior), zgodnych z intencją autorską i ją znie- 
kształcających, kompletnych i zdefektowanych, poprawnych i skażonych błędami. W jednej z klasycznych prac porządkujących teoretyczne wskazania dla edytorów na gruncie polskim, jaką jest Tekstologia i edytorstwo dziet literackich Konrada Górskiego (Warszawa 1975) ${ }^{6}$, błędom tekstu poświęca się kilka rozdziałów, rozważając ich źródła, sposoby rozpoznawania, metody demaskowania apokryfów oraz granice dopuszczalności wprowadzania korekt. Do chwalebnej ostrożności w poprawianiu tekstu Górski przywiązuje ogromną wagę, uznając koniekturę (poprawkę hipotetyczną) za zło konieczne, wymuszone jedynie przez oczywistą nonsensowność lub fizyczne uszkodzenie przekazu, i powtarzając za swoim mistrzem, Juliuszem Kleinerem: „Z dwojga złego [...] lepiej pozostawić błąd pierwodruku, niźli wzbogacić utwór błędem wydawcy”. Wszyscy bowiem jesteśmy omylni.

Numer rocznika poświęcony błędom zamyka dział Varia, w którym wśród tekstów o różnorodnej tematyce znajduje się artykuł Barbary Tyszkiewicz, ukazujący starcie metodologii, perspektyw badawczych i kolejnych pokoleń badaczy w krzywym zwierciadle środowiskowej satyry (Btad centrali - bunt w terenie. Humorystyczny obraz poczatków Instytutu Badań Literackich w „NaKuBi” oraz „Etiudzie rewolucyjnej" Krystyny Tokarz i Teresy Tyszkiewicz), a także prace studentów warszawskiej Akademii Sztuk Pięknych, które przedstawiają plastyczną interpretację tematu. Bogato reprezentowany jest również dział recenzji - specyficznego gatunku, którego zadanie wiąże się z oceną wartości i prawdziwości cudzej pracy: pochwałą osiągnięć autora książki i wskazaniem jego niedociągnięć.

Wiedza o własnej omylności uczy badacza dokładności i pokory, wyczula na potrzebę nieustannego sprawdzania swojej pracy, czyni otwartym na konstruktywną krytykę. Jej świadomość jest zatem niezwykle cenna, wręcz niezbędna w każdej pracy naukowej. O tym, czy błąd będzie szczęsny, czy katastrofalny, czy stanie się źródłem nauki, czy gorzkiego zawodu, decyduje w istocie postawa błądzącego. Dobrą ilustracją tego twierdzenia jest anegdota przytoczona przez Richarda Dawkinsa na kartach jego książki o „złej i dobrej poezji nauki”, trudnej sztuce popularyzacji oraz naturze badań naukowych:

\Aroganccy czy nie, tak czy inaczej deklarujemy, że postęp nauki odbywa się też w drodze obalania niektórych jej hipotez. Konrad Lorentz, ojciec etologii, z charakterystyczną dla siebie przesadą mówił nawet, że nie może sobie odmówić obalenia co najmniej jednej ulubionej

6 Jest to poprawiona i rozwinięta wersja wcześniejszej pracy Konrada Górskiego Sztuka edytorska. Zarys teorii, Warszawa 1956.

7 Idem, Tekstologia i edytorstwo dziet literackich, wstęp M. Strzyżewski, oprac. M. Ławrynkowicz, A. Markuszewska, M. Strzyżewski, wyd. 3 uzup. i popr., Torun 2011, s. 75-76. 
hipotezy dziennie przed śniadaniem. [...] W czasie moich pierwszych lat studiów w Oksfordzie jedno z takich wydarzeń, o niezwykle budującym wydźwięku miało miejsce w czasie wizyty pewnego wykładowcy z Ameryki. Przedstawił on dowód ostatecznie obalający ulubioną teorię pewnego wysoce szanowanego starszego przedstawiciela elity naszego wydziału zoologii, teorię, na której wszyscy się wychowaliśmy. $\mathrm{Na}$ koniec wykładu ów starszy profesor wstał, wyszedł zdecydowanym krokiem przed audytorium, potrząsnął serdecznie dłonią Amerykanina i stwierdził głosem wibrującym od emocji: „Drogi kolego, pragnę panu podziękować. Od piętnastu lat tkwiłem w błędzie, a pan mnie z niego wyprowadził”. Biliśmy brawa do bólu dłoni. Czy jakakolwiek inna grupa zawodowa przyznaje się do błędów z podobną wielkodusznością?

Tytuł naszego numeru wykorzystuje tylko pierwszą, bardziej znaną część łacińskiej maksymy, przypisywanej różnym myślicielom (Senece, Cyceronowi, świętemu Augustynowi). Jej drugi człon występuje w rozmaitych wersjach, akcentujących zło lub głupotę uporczywego trwania w błędzie - można go zatem odczytywać jako przestrogę o wymowie etycznej (przed manipulacją lub nieuczciwością rozpowszechniania fałszywej informacji), albo też pragmatyczną radę dotyczącą wyciągania nauki z własnych i cudzych omyłek. Powiedzmy łagodniej: Errare humanum est, sed in errore perseverare insipientis. Nierozsądnie jest - nawet z dobrych pobudek - świadomie pozostawać w błędzie.

Wyrozumiałość dla naturalnej ludzkiej skłonności do błędów nie powinna skłaniać do pozostawiania omyłek nieskorygowanych. Będąc omylnymi - i świadomymi swej omylności - tym bardziej powinniśmy dążyć do tworzenia dzieł jak najmniej skażonych błędami.

8 R. Dawkins, Rozplatanie tęczy. Nauka, ztudzenia i apetyt na cuda, tlum. M. Betley, wyd. 4, Warszawa 2010, s. 41. Tytuł książki stanowi przewrotne nawiązanie do poematu Johna Keatsa Lamia (1820), w którym romantyczny poeta oskarża zimnych badaczy, że swoją analizą odzierają świat z mistycznego czaru („Filozof skrzydła anioła obetnie [...] Tęczę rozprzędzie” - cyt. za: J. Keats, Poezje wybrane, tłum. Z. Kierszys, Warszawa 1962, s. 80). 